Covered in: Web of Science (WOS); EBSCO; ERIH+; Google Scholar; Index Copernicus; Ideas RePeC; Econpapers; Socionet; CEEOL; Ulrich ProQuest; Cabell, Journalseek; Scipio; Philpapers; SHERPA/RoMEO repositories; KVK; WorldCat; CrossRef; CrossCheck

2020, Volume 11, Issue 3, pages: 207-219 | https://doi.org/10.18662/po/11.3/208

\title{
Postmodern Picture of Reality of Scientific Knowledge: Evolution by Epistemological Diversity
}

\section{Volodymyr BEKH ${ }^{1}$, Alla YAROSHENKO' ${ }^{2}$, Tetiana ZHYZHKO 3 , Vatiliy IGNATYEV 4 , Roman DODONOV 5}

\section{${ }^{1}$ National Pedagogical}

Dragomanov University, Kyiv, Ukraine bvp4171@yahoo.com ${ }^{2}$ National Pedagogical Dragomanov University, Kyiv, Ukraine yaroshenkonpu@i.ua ${ }^{3}$ National Pedagogical Dragomanov University, Kyiv, Ukraine zhuzhkott@i.ua

${ }^{4}$ Donetsk National Medical University, Ukraine va.ignatyev@i.ua

${ }^{5}$ Borys Grinchenko Kyiv University, Kyiv, Ukraine dodonovr68@gmail.com
Abstract: The modern world is colorful, diverse, contradictory and not without contradictions. Accordingly, the problems of the modern world are a combination of various problems closely intertwined and interconnected. So, the study of the fundamental foundations of cognition becomes relevant, among which the postmodern methodology stands out as particularly pluralistic, in its development it responded to the trends of the time and was always aimed at solving problems of a particular person, distinguished by the "humanity", "reality" of thought. Within the framework of postmodernism, representatives of this trend pose problems that are difficult to solve. Firstly, this is due to the fact that postmodernists claim that, on the one hand, speech-discourse constructs reality, and on the other, reality itself determines discourse. Secondly, they emphasize that there is no place for a general theory either in science or in humanitarian studies, while this statement is part of theoretical knowledge. Third, in discussing consumer society, cultural pluralism, postmodernists turn to "realistic ontology". So, putting forward the thesis that society is a kind of product of discourse, they voluntarily or involuntarily uphold the idealistic epistemology. The ideas of postmodernism can be perceived very differently. A certain number of people may "not accept" the views of postmodernism, depriving its representatives of an essential role in modern philosophy of science.

Keywords: postmodernism; pluralism; methodology of knowledge; philosophy of science; postpositivism.

How to cite: Bekh, V., Yaroshenko, A., Zhyzhko, T., Ignatyev, V., \& Dodonov, R. (2020). Postmodern Picture of Reality of Scientific Knowledge: Evolution by Epistemological Diversity. Postmodern Openings, 11(3), 207-219.

https://doi.org/10.18662/po/11.3/208 


\section{Introduction}

The second half of the twentieth century. is marked by new trends in views on logical positivism. It was during this period that the indicated philosophical trend was criticized "from within." Such ideas as the principle of falsification of Ardashkin (2007), the theory of scientific revolutions of Epstein (1999) were formed precisely in the framework of positivist philosophy. The views of Ardashkin (2007) and Feyerabedn (1981) were called "historical relativism." Representatives of this direction believed that scientific knowledge is due to historical and social factors, and therefore it is not absolute in nature. The purpose of scientific activity is not only in the statistical accumulation of facts obtained as a result of empirical research, therefore, scientists are faced with the task of understanding reality as a manifestation of more fundamental processes. Such processes take the form of similar laws of models, or "patterns," explaining the phenomena of objective reality. Thus, this reality is not limited to the totality of observations: in the process of developing scientific knowledge, there is some transcendental "remnant" along which deeper levels of being lie. In the post-Kantian ideas, it was noted that theories should not be compared with empirical facts, but with models, which, in turn, must be compared with the statements of observation.

It is worth noting that, according to experts, the scientist's imagination and ingenuity in scientific research plays a significant role in the processes of cognition. Attention in this case focuses not so much on the logical and methodological approach to the study of scientific knowledge, but rather on the study of sociocultural and personality-worldview factors in science.

The concept of the objectivity of scientific knowledge has several interpretations - from the positivist and non-positive sides. From the point of view of positivists, the scientist from the first steps of his research should get rid of axiological or linguistic prerequisites, examining the object directly, "from scratch." This kind of objectivity is unattainable in practice, since it is impossible for a scientist to completely get rid of value, linguistic, conceptual attitudes. For another, objectivity can be considered as self-limiting requirements, according to which a scientist brings his value preferences according to empirical data, so that science can be separated from ideological layers.

Direct and feedback on the one hand exists between theory and model, on the other hand, between model and empirical facts. Thus, 
according to certain requirements of the model, if theories do not correspond to the facts, they can be corrected and revised, and the empirical facts themselves can be subjected to further verification if they are not consistent with the model. The indicated concept of science is "naturalistic", since within its framework natural sciences (in particular, physics) act as a certain paradigm for all other sciences. So, theories and models must find their mathematical expression. However, one should take into account the fact that any science can be studied not only using quantitative, but also qualitative methods. For example, if quantitative methods are aimed at using numbers and formulas, then qualitative methods are based on metaphors and analogies.

\section{Basic philosophical views}

Representatives of positivism attributed the logical form to a theoretical statement, thereby identifying the rational with the logical. However, not everything that is considered rational should be in a logical framework, since if the process of scientific research is limited to the framework of formal logic, then something irrational remains beyond it. Representatives of postpositivism — Feyerabedn (1981), Ishenko (2006) actively substantiated these ideas in their works.

In his scientific achievements, Polanyi \& Prosch (1975) predicted modern concepts of philosophy and methodology of science, so the researcher can be attributed to the category of "unsystematic" philosophers who tried to realize the actual changes in science and propose their own principles of methodological analysis. The basic principles of Polanyi \& Prosch (1975) author's concept include the following:

- Scientific proposals are not simple descriptions of observations; therefore, their truth or falsehood cannot be established in the process of observation. Even in physics, judgments of probability are inevitable, where probability does not appear as an observable fact, but as a result of a personal assessment, lies outside these facts;

- According to Polanyi \& Prosch (1975), when two scientific theories collide, the decisive criterion should not be the fact that one theory corresponds to empirical facts and the other does not. Any facts can be brought closer to the theory if they are interpreted in its light. To change any theory, it is necessary not only to appeal to facts, but to completely change the very framework of interpretation;

- Knowledge should always be combined with the intellectual feeling of a person. Scientific ideas do not become part of science until others see 
them, until they are believed in. This plays a role in determining what is and is not a "science";

- Knowledge cannot be fully formulated, since no formula can determine the boundaries of its own application, but this application affects the significance and validity of the formula;

- Knowledge of the outside world has a metaphysical basis; philosophical foundations is an integral part of science itself.

Philosopher Feyerabedn (1981) stated that in science "everything is permitted." According to this thesis, both business entities in economics and scientific theories must compete among themselves, thereby creating the foundation for new theories and practices. Competitive theories appear in the scientific community as a "decisive" means of criticism of an accepted theory based on a comparison of theory with established facts. As a result, it turns out that it is not the facts that do not agree with the theory that they take precedence over alternative hypotheses, but due to the rejection of alternative hypotheses, the facts are eliminated, potentially refuting the accepted theory.

From the point of view of Feyerabedn (1981), theories with a high degree of empirical recognition become almost integral to myth and exist solely through associations of believers and leaders. In this sense, astronomy is not much different from astrology, and chemistry - from alchemy. According to the philosopher, the competition of theories should provide such conditions for scientific activity that allow even the most meaningless ideas of the human mind to exist.

The main method of scientific knowledge in Feyerabedn (1981) is "fruitful" relativism. The belief in "approaching the truth", according to the researcher, only puts barriers to human knowledge. According to the author's concept, the cognitive process is a complex of mutually disparate alternatives, where each individual theory is part of one aggregate. The incommensurability of competing theories means the impossibility of comparing them in terms of truth or plausibility. In this case, according to Feyerabedn (1981), only aesthetic judgments, taste and individual desires remain. According to Feyerabedn (1981), a scientific revolution and the victory of a new paradigm are impossible as long as academicians supporting the old paradigm remain at the head of scientific institutes. It should be noted that such views are no longer consistent with the principle of falsification Pykhtina, (2018).

In turn, Mouzelis, (2007) introduced a certain pragmatic aspect into the philosophy of science, according to which theories are entities, they are not only verified but used. Mouzelis, (2007) compares theoretical statements 
with the description of the rules: before using the rule, scientists limit the scope of its application, but even in a particular industry the rules do not apply to all cases without exception. For example, in most countries, killing a person is punishable by law, except in situations where death occurs during hostilities. With a similar example, Mouzelis (2007) shows how, according to the logic of positivism, scientists are faced with difficulties trying to identify the scope of one or another theoretical statement. So, any rule, according to the scientist, is evaluated not so much from the point of view of "truth" or "falsity" as by the industry of its application.

Since the "scientific facts" from a philosophical vision are mostly ambiguous, Mouzelis (2007) believes that it is impossible to separate the scientific and philosophical aspects of human understanding, but they can be corrected. The author comes to the conclusion that neither the world with which a person is dealing, nor the totality of concepts, methods and beliefs are historically unchanged. According to his views, the main features of the development of science are similar to the Darwinian population theory of variability and natural selection.

Rethinking the theory of knowledge is closely related to the development of philosophy and methodology of science. The implementation of this trend is due to the appeal to new ideas on the interpretation of the process of scientific knowledge. The post-positivist trend, which replaced logical positivism, only strengthened faith in the philosophy of science. Representatives of this trend were Naimushin (2007), who concentrated their attention precisely on the process of scientific research. Unlike their predecessors, which were limited only to a description of this process, postpositivists sought to obtain objective knowledge through experience.

The concepts of representatives of post-positivism influenced the evolution of Western philosophy of science, in particular, the formation of the Edinburgh school, whose representatives put forward a "Strong Program", and established "social constructivism" in the sociology of knowledge. In their works Jonsen \& Toulmin (1988) and Ishenko (2018) turned to the history of science, often using examples, because of which they began to be ranked as a "historical" trend in the philosophy of science.

In modern philosophy of science, there is a departure from abstract methodological schemes in favor of historical research. So, since the 1980s. in works on the philosophy of science, more attention was paid to the ethical problems of science. Among the representatives of bioethics Beauchamp \& Childress (2001) in the famous book "Principles of Biomedical Ethics" examples from the history of medicine were also widely 
used. Present biomedicine, using the "general norms of scientific reports", resembles paradigm. These standards are based on probability theory and allow you to compare the effectiveness of different treatments.

Over time, Jonsen \& Toulmin (1988) in his work turned to the development of a new research method - reasoning based on specific cases, became a kind of prerequisite for the formation of such a philosophical trend as postmodernism. Both post-positivists and representatives of postmodernism are united by the idea of pluralism. It is no coincidence that postmodernism is associated with the method of "polyphonic research."

The credibility of traditional myths or, as Ilyn (1998) said, "idols of the theater", is a factor of limiting and suppressing polyphony. Proponents of postmodernism call for epistemological diversity so that every "voice from the choir" is heard. Both post-positivists and post-modernists reject the idea of a methodology according to which the facts are "primary" and the theory "secondary". Both directions do not share the idea of objectivity in the sense of "axiological neutrality" of scientific knowledge. However, post-positivists emphasize value and socio-historical factors, and representatives of post-modernism - on the linguistic aspects of the cognitive process. According to postmodernists, not a single law, not a single norm can escape the influence of language, and reality exists only within the framework of the "language game", and only changes in consciousness or will are able to transform possible interpretations into a dominant picture of reality.

The roots of postmodernism come from an atmosphere of uncertainty, skepticism and pluralism, which was observed in the period after the Second World War. This cultural movement originated in the 1960s, expanded and began to influence the world as a whole in the 1970s, became popular in the 1980s and received an academic form of expression in the 1990s, but since the mid-1990s there has been a decline social science movements. The post-modernists in the 1960s called the union of American writers who claimed an unusual way of presenting material, but subsequently this term extended to the humanities, art, and architecture.

From the very beginning, postmodern energy was directed against the "metaphysical" idea of the existence of rational general principles that condition the progress of scientific knowledge. According to the views of the representatives of postmodernism, such principles are nothing more than myths, "global stories", "meta-look". Myths act as the foundation for controlling human behavior, forming coercion of a person with the help of symbols (Markova, 2019). In this case, obedience and conformism are 
achieved through the use of language, with the help of which myths are first justified as certain ideals, and then introduced into people's consciousness.

According to experts, myths and meta-info exist to eliminate alternative ways of thinking and behavior, and control with the help of symbols becomes possible due to the difference between fact and assessment. Today, it is generally accepted that scientific views have an undeniable advantage over others. Since the language of science is more formalized, and less subject to prejudice, it presents a more objective description of reality than any other.

If you interpret the time from the standpoint of the movement of a mechanical watch, it will be meta-specific, during which time "maths", is presented in the form of an endless set of moments - discrete and selfsufficient. Since the present reflects the moment between the past and the future, this idea goes back to the tradition of empiricism, according to which the subject with the help of sensory impressions captures only the present, which is reflected in his consciousness (Meshcheryakova, 2019). Thus, time becomes mechanical, falling within the terms of physics. Proponents of this interpretation ignore the fact that any notion of time is indirectly interpreted. Postmodernists believe that time must be viewed through the prism of human experience, since it is it that allows the individual to remember the past, identify the present and possibly even predict the future. According to Sibeon (2007), time has the ability to move, but this movement is expressed not so much in space as in switching the attention of consciousness. According to the past, this is not something that has disappeared in time, but the present, which has lost a certain meaning for a person. "Philosophical time," write "is a time of general coexistence, where" before "and" after "are not excluded, but overlap each other".

Reality is formed with the help of symbols, therefore, there is no difference between theory and objective reality. Thus, if the reality is a system of "stories" or "texts", its description is purely texts along with other texts. You can find a pattern, various objects of reality can have excellent interpretations, depending on the field of knowledge. As an example, we can cite a "tree" as an object of reality, in different areas it has its own status: as an object of aesthetic perception, as a resource for the implementation of certain projects, as a system for saving humanity from environmental disaster. So, the subject of science is constructed in the process of reflection and is formed not as an "external", but as an "internal" object in relation to science (Shestakova, 2018). Theory to a greater extent constructs, but does not explain, the phenomena of the objective world. 
Representatives of transhumanism consider the issue of temporary space to be extremely important, therefore they set themselves the goal of expanding a person's idea of time. The problems of this trend present prospects for fundamental changes in human life. Today's nanotechnology exists in healthcare to prevent and treat disease. Transhumanism indicates that representatives of nanotechnologies set themselves the goal of "crossing" the border of human capabilities in order to expand the boundaries of age, emotional relationships with other people, and attitudes towards other living beings. Researchers believe that under such conditions, it is possible to bring a person to a new level of existence, where on the one hand attention is focused on improving the conditions of human life within the boundaries of humanity, on the other hand, on improving conditions through "superstructure", "stepping over" the boundaries of human capabilities. In other words, trans-humanism is not talking about improving living conditions, but is aimed at "improving" a person as an object of this world. A fundamental change in a person can mean, for example, a significant increase in a person's age, brings it closer to immortality. Under the conditions of assessing the truth and objectivity, scientific knowledge is supplemented by value-goal settings not only on efficiency, but also on justice, humanism, beauty.

Now the modern world is on the verge of the emergence of new sciences, where any form of regulation is discarded. As a result of this, the meaning of the process of cognition changes: it is unknown to replace the known, while the effective is replaced by a new one that differs from the already familiar one. Postmodernists play an important role in the imagination, because they believe that only with its help the subject is able to comprehend the new, which determines the pluralism of research programs.

\section{The philosophical premises of postmodernism}

As the philosophical prerequisites of postmodernity, the teachings of Arxer, Murphy \& Belgrave, (2007) are distinguished. Among the representatives of postmodernism, the concept of science and knowledge, an approach to philosophy with a linguistic bias of Arxer, Murphy \& Belgrave (2007) a psychoanalytic approach to the philosophy of Arxer, Murphy \& Belgrave, (2007), an ironic style of literary presentation by Ilyn, (1998).

The task of philosophy Springer De Freitas \& Pietrobon, (2007) see in each case, to find an instance that can measure only one true value among opposing opinions, choosing wiser. According to the authors, such a concept is only an opinion plan of being created by opinion. Based on the 
ideas of F. Nietzsche, they emphasize that thought is creativity, and not the will to truth. According to scientists, the truth can be determined only through the formulas "turn to ..." or "what the thought refers to" (Springer De Freitas \& Pietrobon, 2007).

The French philosopher Descartes identified two components of knowledge: limited understanding and limitless freedom. According to the author, the subject of knowledge in the framework of the classical type of rationality required evidence that he would come to on his own. But while he doubted everything, even the obvious one, that $3+2=5$, he questioned any truths of Nature. According to the subject, in the framework of the post-nonclassical type of rationality, he does not strive for the obvious, therefore he will never agree that $3+2=5$ Thus, the individual desires absurdity as another way of thinking. So, the subject in the framework of the classical type of rationality wanted truth, the subject of the post-nonclassical type seeks to make the idea absurd above.

The subject of logical consideration the moment when the evolutionary period in the development of science ends, and aspiration for another variable occurs - the period of the scientific revolution. Under these conditions, post-positivists have the problem of the incommensurability of competing theories, while fall into a different type of thinking, a different reference based on another encounter with the virtual world of chaos (Alvesson \& Skoldberg, 2009). In this situation, there is a fundamental difference between the position from the dominant tendency to explain the revolutionary periods in the 20th century in the framework of postpositivism, since in the second case science was viewed through the prism of the world of culture, society, the scientific community, proceeding from the sphere of logic, and in Alvesson \& Skoldberg (2009), science fell into the world of processes that take her out of chaos. It is this world that is explained by the means of logic, developed by Alvesson \& Skoldberg (2009). Such a confrontation raises the question: what is the logic of the emergence of all these methods of scientific thinking from the indefinite and unscientific?

According to the philosophy of Alvesson \& Skoldberg, 2009, the relations between the subject and the subject of scientific research turn into relations between things formed by science, which acquire the ability to perceive and feeling through "private observers". However, it cannot be argued that natural processes occur objectively, regardless of the subject, but they cannot be connected either. The subject in the process of cognition is pushed into the background, thereby giving way to a private observer, the perception of which is not subjective in nature (Alvesson \& Skoldberg, 
2009). A similar phenomenon forms the classical dualism of the subject and object of cognition, solved in Science using the concept of a private observer. "No matter how historical and historically reliable those personal names that are associated with the statements, they are just masks for other beings, just pseudonyms for more mysterious single entities". "In the case of proposals, these are external private observers who are scientifically determined with respect to one or another axis of reference".

Science conception reveals the hypothesis that as society enters the post-industrial era and culture enters the post-modern era, the status of knowledge changes. The increase in the number of information machines occupies and will continue to occupy the same place in the dissemination of knowledge that occupied the development of human vehicles, sound and images. With such a general change, the nature of knowledge cannot remain unchanged, but it can be assumed that all areas of new research will be subject to the condition of the transition of possible results to the language of machines. In accordance with this, producers and users of knowledge will have to have means of translation into these languages of what some seek to invent, and others to learn. Thus, information becomes a means in the struggle for power, and knowledge circulates in the same way as cash flows.

The pragmatism of knowledge, according to Mendelsohn (1977), takes precedence over the semantics of meaning and significance, therefore the criterion for knowledge is not objectivity, but practical usefulness and efficiency. Strengthening the pluralism of language games leads to unlimited relativism, which contributes to the advantage of the language game of technical science over all others. Thus, the science of technology subordinates the knowledge of power, science to politics and economics, and follows the rule according to which "reason is always the mind of the strong." However, Mendelsohn (1977) believes that neither science, nor even techno-science, can claim the role of a unifying and determining principle in society. The scientist avoids the idea that one position can be suppressed by another, so he sees a way out only in the rejection of the universalization and absolutization of anything, in the affirmation of true pluralism. Instead of the positivistic principle of verification and the postpositivist concept of falsification, offers a "double rule". A scientific decision, or to achieve objectivity according to Mendelsohn (1977), is to abide by this rule. He concludes that we need to "form equal". A rule of thumb allows you to provide a dispute between partners, the sender and the recipient of knowledge, the horizon of consensus.

The proof of truth in science is compared by Mendelsohn (1977) with the adoption of law in parliament. The progress of science is a 
movement in which knowledge is accumulated, thereby spreading this movement to a new socio-political subject. The people are arguing about justice, and the community of scientists is talking about what is true and what is false. The first union accumulates civil laws, the other scientific; the first improves the rules of its consensus through constitutional provisions in the same way as the second reviews them in the light of its knowledge, while producing new "paradigms". The truth is those statements about which an exchange of arguments and evidence has already taken place. These statements are no longer subject to discussion.

Comparing scientific and unscientific knowledge, Mendelsohn (1977) concludes that the existence of the first necessity is no more than the second, but no less. To justify the objectivity of knowledge, scientists are forced to seek help from "external factors". Scientific knowledge will not be able to demonstrate its truth if it does not resort to other knowledge - stories that are ignorance for him.

An important factor in affirming the truth is the help of science from those in power. "The state can spend a lot of money on something," writes Mendelsohn (1977) "so that science can be presented as an epic: with its help, it inspires confidence, creates public approval". But the development of such a concept is possible only when the "language game of science" seeks to reach the truth of its statements, but does not have the ability to legitimize it by its own means. The question of the state is thus closely intertwined with the question of the objectivity of scientific knowledge.

\section{Conclusions}

Summing up the above, we can conclude that the search for the objectivity of knowledge among representatives of postmodernism is limited by the rules of dispute, epistemology is supplanted by rhetoric, the process of cognition by didactics, the dialectic of research by the game of the formation of scientific knowledge, the activities of the scientist by the language game. Within the framework of postmodernism, the distinction between subjective and objective is erased.

At the same time, when studying relativism, it is necessary to single out its various meanings. So, on the one hand, the moment of relativity as variability, instability, associated with the individual characteristics of the cognizer, is absolutized, and in this case this phenomenon acts as a method of cognition, and on the other hand, relativism is understood as taking into account the conditioning of the process of scientific knowledge by 
Postmodern Picture of Reality of Scientific Knowledge: Evolution by ... Volodymyr BEKH, et al.

numerous factors, and In this sense, it is a necessary moment of scientific progress.

The contribution of the postmodern trend to the modern philosophy of science is not limited to the thesis of the variability of knowledge. So, Springer De Freitas and Pietrobon (2007) proposed one way to solve the problem of the theoretical workload of observation statements, problems that make it difficult to interpret scientific knowledge as objective. The authors put forward the idea of an observer, mentally isolating him from the sociocultural context. The postmodern picture of reality is a reflection of the modern development of science, and is an attempt to overcome the pressing problems of mankind.

\section{References}

Alvesson, M., \& Skoldberg, K. (2009). New vistas for qualitative research (second edition). SAGE Publications Ltd.

Ardashkin, I. (2007). Continuity of the problem as a feature of its ontological status in the context of the philosophy of J. Deleuze. Bulletin of the Tomsk Polytechnic University, 310(3), 138-142.

Arxer, S., Murphy, J., \& Belgrave, J. (2007). Temporality and old age: a postmodern critique. In J.L. Powell \& T. Owen (Eds.), Reconstructing Postmodernism: Critical Debates (pp. 125-140). Nova Science.

Beauchamp, T., \& Childress, J. (2001). Principles of biomedical ethics. Oxford.

Epstein, M. (1999). Toward a Philosophy of the Possible. Introduction to the postcritical era. Questions of philosophy, 6, 59.

Feyerabedn, P. (1981). Problems of empiricism. Philosophical papers. Cambridge, 2, 2345.

Ilyn, I. (1998). Postmodernism from its beginnings to the end of the century: the evolution of a scientific myth. Intrada Journal, 200-220.

Ishenko, E. (2018). Problema real'nosti u filosofs'ko-humanitarnomu dyskursi [The problem of reality in philosophical and humanitarian discourse]. Bulletin of Moscow University. Series 7, Philosopby, 2, 3-20.

https://cyberleninka.ru/article/n/problema-realnosti-v-filosofskom-igumanitarnom-diskurse/viewer

Ishenko, E. (2006). Hnoseolohiya XX stolittya: tendentsiyi ta perspektyvy [Epistemology of the XX century: trends and prospects]. Vestn. Voronezh state. un-that. Ser. 1. The bumanities, 2, 166-180. http://nbuv.gov.ua/UJRN/Pib 20065316

Jonsen, A., \& Toulmin, S. (1988). The abuse of casuistry: history of moral reasoning. University of California Press. 
Markova, L. (2019). Philosophy from chaos. J. Deleuze and postmodernism in philosophy, science, religion. Canon +

Mendelsohn, E. (1977). The social construction of scientific knowledge. In E. Mendelsohn, P. Weingart, \& R. Whitly (Eds.), The social production of scientific knowledge. Sociology of the Siences (pp. 3-26). Dordrecht.. URL: https://www.springer.com/gp/book/9789027707758

Meshcheryakova, L. (2019). Vesvit - teatr: predmetna ta dyskursyvna praktyka yak metod sotsial'noho piznannya [The whole world is a theater: subject and discursive practice as a method of social cognition]. Bulletin of the Ros. University of friendship of peoples. Series: Sociology, 2, 127-133. https://teacode.com/online/udc/50/502.5.html

Mouzelis, N. (2007). Cognitive relativism: between positivistic and relativistic thinking in social sciences. In J.L. Powell \& T. Owen (Eds.), Reconstructing Postmodernism: Critical Debates (pp. 15-28). Nova Science.

Naimushin, V. (2007). Post-industrial mythology as a "borrowed text." Terra Economicus, 5(3), 85-88.

Polanyi, M., \& Prosch, H. (1975). Meaning. University of Chicago Press.

Pykhtina, T. (2018). On the issue of systemic science in the light of postmodernism. Ideas and ideals, 2(12, T.2), 35-40.

Shestakova, M. (2018). Indyvidual'ne myslennya v konteksti pryntsypu plyuralizmu [Individual thinking in the context of the principle of pluralism]. Bulletin of Moscow University. Series 7. Philosophy, 4, 3-18.

https://cyberleninka.ru/article/n/individualnoe-myshlenie- $v$-konteksteprintsipa-plyuralizma

Sibeon, R. (2007). An excursus in post-modern social science. In J.L. Powell \& T. Owen (Eds.), Reconstructing Postmodernism: Critical Debates (pp. 29-40). Nova Science.

Springer De Freitas R. \& Pietrobon R. (2007). Whoever could get rid of the context of discovery. Context of justification dichotomy? A proposal based on recent developments in clinical research. Journal of medicine a. philosophy. Georgetown, 32(2), 25-42. 